\title{
Assessment of Body Image: Instruments Available in Brazil
}

\author{
Gabriela Salim Xavier - Universidade de São Paulo, Ribeirão Preto, Brasil \\ Sonia Regina Pasian - Universidade de São Paulo, Ribeirão Preto, Brasil \\ Sebastião Sousa Almeida - Universidade de São Paulo, Ribeirão Preto, Brasil
}

\begin{abstract}
Because of the increasing number of Brazilian studies on body image (BI), the aim of the present study was to review Brazilian scientific research on the construction and adaptation of systematic assessment instruments for this construct. After conducting a broad literature search, 34 BI assessment studies were analyzed, including 27 adaptation studies and seven construction studies. The results were summarized based on the procedures that were used for the adaptation and construction of BI assessment instruments, indicating strong convergence among most researchers with regard to national and international recommendations on techniques to drive such processes and test the psychometric properties before implementing the instruments in professional practice.

Keywords: body image, assessment instruments, transcultural adaptation, literature review, psychometrics
\end{abstract}

\section{Avaliação da Imagem Corporal: Instrumentos Disponíveis no Brasil}

\section{Resumo}

Em razão de crescente aumento na frequência de estudos brasileiros relativos à imagem corporal (IC), este trabalho objetiva apresentar panorama das investigações científicas nacionais acerca da adaptação e construção de instrumentos sistematizados de avaliação desse construto. A partir de levantamento na literatura científica, foram selecionados, recuperados e integralmente analisados estudos referentes a 34 instrumentos avaliativos da IC, sendo 27 adaptados e os demais construídos. Os resultados foram sistematizados com base em procedimentos empregados para adaptação e construção de instrumentos avaliativos da IC e indicam forte convergência entre a maioria dos pesquisadores no tocante às principais recomendações nacionais e internacionais para condução técnica de tais processos, inclusive em relação à verificação de propriedades psicométricas antes da efetiva utilização na prática profissional.

Palavras-chave: imagem corporal, instrumentos de avaliação, adaptação transcultural, revisão de literatura, psicometria

"Evaluación de laImagen Corporal: Instrumentos Disponibles em Brasil

\begin{abstract}
Resumen
Debido a la frecuencia cada vez mayor de trabajos brasileños sobre la imagen corporal (IC), este estudio tiene como objetivo presentar una visión general de la investigación científica nacional sobre la adaptación y construcción de instrumentos sistematizados de evaluación de este constructo. Después de realizar una revisión de la literatura científica fueron seleccionados, recuperados y analizados estudios referentes a 34 instrumentos evaluativos de la IC, siendo 27 adaptados y el resto construidos. Los resultados se resumen a partir de análisis de procedimientos empleados para la adaptación y construcción de instrumentos evaluativos de la IC e indican una fuerte convergencia entre la mayoría de los investigadores con respecto a las principales recomendaciones nacionales e internacionales para seguir técnicamente esos procesos, incluso en relación a la verificación de las propiedades psicométricas con anterioridad a su uso efectivo en la práctica profesional.

Palabras clave: imagen corporal, instrumentos de evaluación, adaptación transcultural, revisión de literatura, psicometría
\end{abstract}

\section{Introduction}

Body image (BI) is a multidimensional construct that involves mental representations of the body, including the size and shape of body structures and feelings, cognition, and behaviors related to them (Cash, 2011). Consensus has been reached among researchers in the field regarding the distinction between two specific components of BI: perceptual and attitudinal/ emotional. The evaluation of $\mathrm{BI}$ components requires different methods and systematic instruments for examination with regard to emotions, behaviors, and cognition (Banfield \& McCabe, 2002).
Various techniques have been developed internationally to evaluate these aspects and components, including questionnaire, self-report, and silhouettescale formats (Gardner \& Brown, 2010). However, a recent analysis of the Brazilian literature on BI (Laus et al., 2014) indicated that despite the significant increase in the number of assessment measures that have become available in the last decade, many studies still use non-validated measures. This indicates that cross-cultural adaptation procedures of assessment instruments deserve greater attention by researchers in the area of BI. 
Technical guidelines delimit the methodological care that should be taken in the cross-cultural adaptation of assessment tools. Among the existing guidelines, recommendations that were synthesized by Beaton, Bombardier, Guillemin, and Ferraz (2002) were adopted by the World Health Organization to maximize semantic, idiomatic, experimental, and conceptual equivalence of original instruments and their adapted versions in different countries and languages. In Brazil, the study by Borsa, Damásio, and Bandeira (2012) addressed key aspects of the steps that are necessary to cross-culturally adapt psychological assessment instruments, emphasizing the need for Brazilian studies in different contexts and their possible applications.

In the field of BI research, which has sharply increased in Brazil in recent years (Laus et al, 2014; Tavares, Campana, Tavares Filho, \& Campana, 2010), there is a clear need to adapt instruments that were originally created in other countries and cultures to the Brazilian population. Campana, Campana, and Tavares (2009) conducted a review of available scales for eating disorder evaluation in Brazil. Gonçalves, Tavares, Campana, Cabello, and Shimo (2012) examined existing national instruments for BI evaluation in women with breast cancer. The most complete critical review of the BI literature in Brazil was recently published by Laus et al. (2014). This analysis of theoretical and methodological advances in the area of $\mathrm{BI}$ is divided into three main areas: population groups studied, BI components investigated, and evaluation measures.

The present study performed a survey of published articles on the cross-cultural adaptation and construction of systematic BI assessment tools in Brazil and describes the procedures that are used in such processes. The cross-cultural adaptation and construction procedures described herein were analyzed within the framework of national and international recommendations in the area. We examined the quality of these processes to provide useful and updated mapping of Brazilian instruments to assess BI.

\section{Method}

This literature review of the adaptation of BI assessment tools was performed by establishing inclusion and exclusion criteria for studies that were found in the surveyed scientific databases, followed by a descriptive analysis of the results. To obtain broad access to studies on the adaptation and construction of $\mathrm{BI}$ assessment tools in the Brazilian context, published in both national and international journals, two databases were selected for this survey: Biblioteca Virtual em Saúde (BVS) and Scopus. The choice of the former was justified by its scope. It coalesces 14 bibliographic databases in health sciences. The latter database has comprehensive mapping of major journals, subjects, and authors from different areas of knowledge. We also consulted the CAPES Digital Bank of Theses to identify studies that have not yet been published.

For the electronic search, we used the keyword "body image," combined with "adaptation" and "Brazil," "adaptation" and "Brazilian," "validation" and "Brazil," "validation" and "Brazilian," "validity" and "Brazil," "validity" and "Brazilian," "translation" and "Brazil," and "translation" and "Brazilian." We also used keywords that are related to validation procedures and translation tools to identify additional articles beyond the small number of studies that used only the keyword "adaptation." We also expanded the search using the keywords "body image" and "scale" combined with "Brazil"/"Brazilian," and "Brazil"/"Brazilian" combined with "body" and "validity"/"validation." In all of the searches, we used the Boolean operator "AND" with unlimited dates of publication of the studies. For the CAPES Digital Bank of Theses, the keyword "body image" was combined with the terms "adaptation," "validation," "validity," and "translation," in addition to combinations with "scale" and "Brazil." The combination "body," "validation," and "Brazil" was also used.

This review was composed of articles that were published in journals that are indexed in the aforementioned databases in English and Portuguese and theses and dissertations in the CAPES Digital Bank of Theses, excluding books, book chapters, abstracts, and papers published in annals of scientific congresses. Articles that appeared with more than one combination of keywords and databases were included only once in the analysis.

All of the results were subjected to inclusion and exclusion criteria in accordance with the objectives of this review. Based on the titles and abstracts, we selected studies whose objectives focused on the cultural adaptation of $\mathrm{BI}$ assessment tools that were not created in Brazil and studies that constructed new instruments on $\mathrm{BI}$ in the Brazilian context. We excluded (1) studies that did not address BI instrument adaptation studies or validation tools for the Brazilian population, (2) studies that used such instruments but did not focus on methodological aspects (i.e., were not about the instrument), (3) studies that focused on adaptation and translation 
into Portuguese in Portugal, (4) theses and dissertations for which we could not obtain the full text, and (5) literature reviews.

Several attempts were made to contact the authors of studies via email to obtain full-text theses and dissertations, in addition to consulting the websites of the respective faculties. Only two theses and one dissertation were not been fully recoverable and therefore excluded. Although it was not identified in the database survey, we also included one article of which we were aware beforehand because it met the study criteria.

The selected and retrieved scientific articles were fully read with regard to the following areas: (1) translation procedures used for adaptation instruments, (2) procedures used in the construction of instruments, and (3) procedures used to investigate the psychometric properties of the adapted and constructed instruments.

\section{Results and Discussion}

The scientific literature searches yielded a total of 1,047 references, with some repetitions in one of the databases and between databases (Table 1).

According to the inclusion and exclusion criteria, we selected 29 articles and 12 dissertations/theses in this study. Thus, the 41 fully recovered studies comprised the basic results of the present study. The descriptive and analytical analyses were based on the instruments that were reported in journal publications because the adaptation or development of instruments in dissertations or theses is oftentimes followed by publication in a scientific journal. As a result, a total of 34 assessment tools were identified in the 41 fully recovered studies on BI. We evaluated the procedures that were used in their adaptation and/or creation, accompanied by an analytical classification (sufficient, regular, or insufficient) according to three aspects: (1) translation procedures, (2) adaptation procedures, and (3) psychometric properties. Based on this classification, we analyzed the procedures according to the scientific literature for cultural adaptation and grouped the studies into three classes: (1) sufficient (two or more translations and/or back-translations, in addition to other necessary procedures, (2) regular (at least two translations and at least one back-translation), and (3) insufficient (only instrument translation).

Among the 34 instruments that were identified for BI evaluation, 27 consisted of adaptations to Brazil, which were mostly presented in English. The main justification that was presented by most authors (12 of
27 instruments) to perform cross-cultural adaptation was the lack of systematic techniques for examining specific constructs of $\mathrm{BI}$ in Brazil. A brief description and characterization of the $27 \mathrm{BI}$ assessment tools that were adapted to the Brazilian context are presented in Tables 2, 3, and 4.

Only seven of the recovered instruments consisted of scales that were originally developed in the Brazilian context (Table 5). The main justification for creating BI assessment tools (presented in five of these seven studies) was, according to the authors, the cultural specificity of the construct in the study, also supported by technical failures in existing instruments in the international literature and the lack of validated and appropriate techniques that focus on BI assessments for use in Brazil. A consensus appears to have been reached among Brazilian authors concerning the justifications for the effort and expense associated with this process, rather than adapting existing evaluative techniques (Pasquali, 2010).

\section{a) Translation Procedures}

Among the $27 \mathrm{BI}$ assessment tools that have undergone adaptation procedures, two of them consisted of silhouette scales (Stunkard Figure Scale and Figure Rating Scale). Thus, for the translation analysis, we considered a total of 25 instruments. This analysis was based on international recommendations for crosscultural adaptation instruments (Beaton et al., 2002) because of its use by the Federal Council of Psychology (2003) in the process of drafting guidelines for regulatory assessment tools that originate from outside Brazil, in addition to the wide use of these recommendations in national studies within the area of health. We considered the number and qualifications of the professionals who were involved in each stage of the process and the procedures that were applied to verify the translated version.

According to Beaton et al. (2002), the valid and effective translation and cultural adaptation of any healthcare assessment tool involves five steps. The first step deals with translation of the original instrument, which should be performed independently by two or more translators whose native language should be the country for which the instrument is being translated, in this case Brazil. One of the translators must know the subject and instrument under study, and the other translator should not be linked to the area of study.

Of the 25 instruments that were analyzed herein, this first procedural step was achieved for adaptation in 
Table 1

Distribution (Single Frequency) of Scientific Database search Results

\begin{tabular}{lcccc}
\hline Keywords & BVS & Scopus & $\begin{array}{c}\text { CAPES } \\
\text { Digital Bank } \\
\text { of Theses }\end{array}$ & Total \\
\hline "Body Image" AND adaptation AND Brazil & 20 & 15 & $* *$ & 35 \\
"Body Image" AND adaptation AND Brazilian & 10 & 9 & $* *$ & 19 \\
"Body Image" AND validation AND Brazil & 12 & 15 & $* *$ & 27 \\
"Body Image" AND validation AND Brazilian & 14 & 15 & $* *$ & 29 \\
"Body Image" AND validity AND Brazil & 21 & 20 & $* *$ & 41 \\
"Body Image" AND validity AND Brazilian & 25 & 20 & $* *$ & 45 \\
"Body Image" AND translation AND Brazil & 15 & 16 & $* *$ & 31 \\
"Body Image" AND translation AND Brazilian & 11 & 13 & $* *$ & 24 \\
"Body Image" AND scale AND Brazil & 41 & 53 & $* *$ & 94 \\
"Body Image" AND Scale AND Brazilian & 41 & 39 & $* *$ & 80 \\
Body AND validity AND Brazilian & 117 & 70 & $* *$ & 187 \\
Body AND validation AND Brazilian & 49 & 56 & $* *$ & 105 \\
Imagem Corporal AND adaptação & $1,409 *$ & $* *$ & 56 & 56 \\
Imagem Corporal AND validação & 34 & $* *$ & 44 & 78 \\
Imagem Corporal AND validade & $2,119 *$ & $* *$ & 20 & 20 \\
Imagem Corporal AND tradução & 57 & $* *$ & 12 & 69 \\
Imagem Corporal AND Escala AND Brasil & 15 & $* *$ & 21 & 36 \\
Corpo AND Validação AND Brasil & 13 & $* *$ & 58 & 71 \\
Total & 495 & 341 & 211 & 1.047 \\
\hline
\end{tabular}

*Not included in the survey because of the number of results that were found from the imprecision of keywords. ${ }^{* *}$ Not applicable, on this basis, this combination of keywords.

13 studies (Male Body Dissatisfaction Scale [MBDS], Body Image Quality of Life Inventory [BIQLI], Swansea Muscularity Attitudes Questionnaire [SMAQ], Drive for Muscularity Scale [DMS], Masculine Body Ideal Distress Scale [MBIDS], Male Body Checking Questionnaire [MBCQ], Sociocultural Attitudes Toward Appearance Questionnaire-3 [SATAQ-3], Body Esteem Scale [BES], Body Appreciation Scale [BAS], Social Physique Anxiety Scale [SPAS], Acceptance of Cosmetic Surgery Scale [ACSS], Body Image Avoidance Questionnaire [BIAQ], and Body Checking Questionnaire [BCQ]). Among the other instruments, variation was found in the number of translators (one to three) in 10 cases (Body Checking and Cognitions Scale [BCCS], Tripartite Influence Scale, Body Change Inventory [BCI], Offer Self Image Questionnaire [OSIQ], Body Checking and Avoidance Questionnaire [BCAQ], Body Areas Scale [BAS], Escala de Evaluación de Insatisfación Corporal para Adolescentes [EEICA], Body Dysmorphic Disorder Examination [BDDE], Body Investment Scale [BIS], and Body Attitudes Questionnaire [BAQ]), all described as researchers in the area and fluent in English. Two other instruments (Body Shape Questionnaire [BSQ] and Eating Behaviours and Body Image Test [EBBIT]) did not provide information on the number or professional qualifications of those who participated in this technical step.

The second step in this process is the synthesis of translations, in which two translators meet with a third party to integrate the two drafts into a single version (Beaton et al., 2002). This step was accomplished in the adaptation of most of the instruments analyzed (18 studies, $72 \%$; i.e., MBDS, BCCS, BIQLI, SMAQ, DMS, MBIDS, MBCQ, SATAQ-3, BES, BAS, SPAS, ACSS, BIAQ, BAS, EEICA, BDDE, BCQ, and BAQ). This procedural step was not mentioned or described 


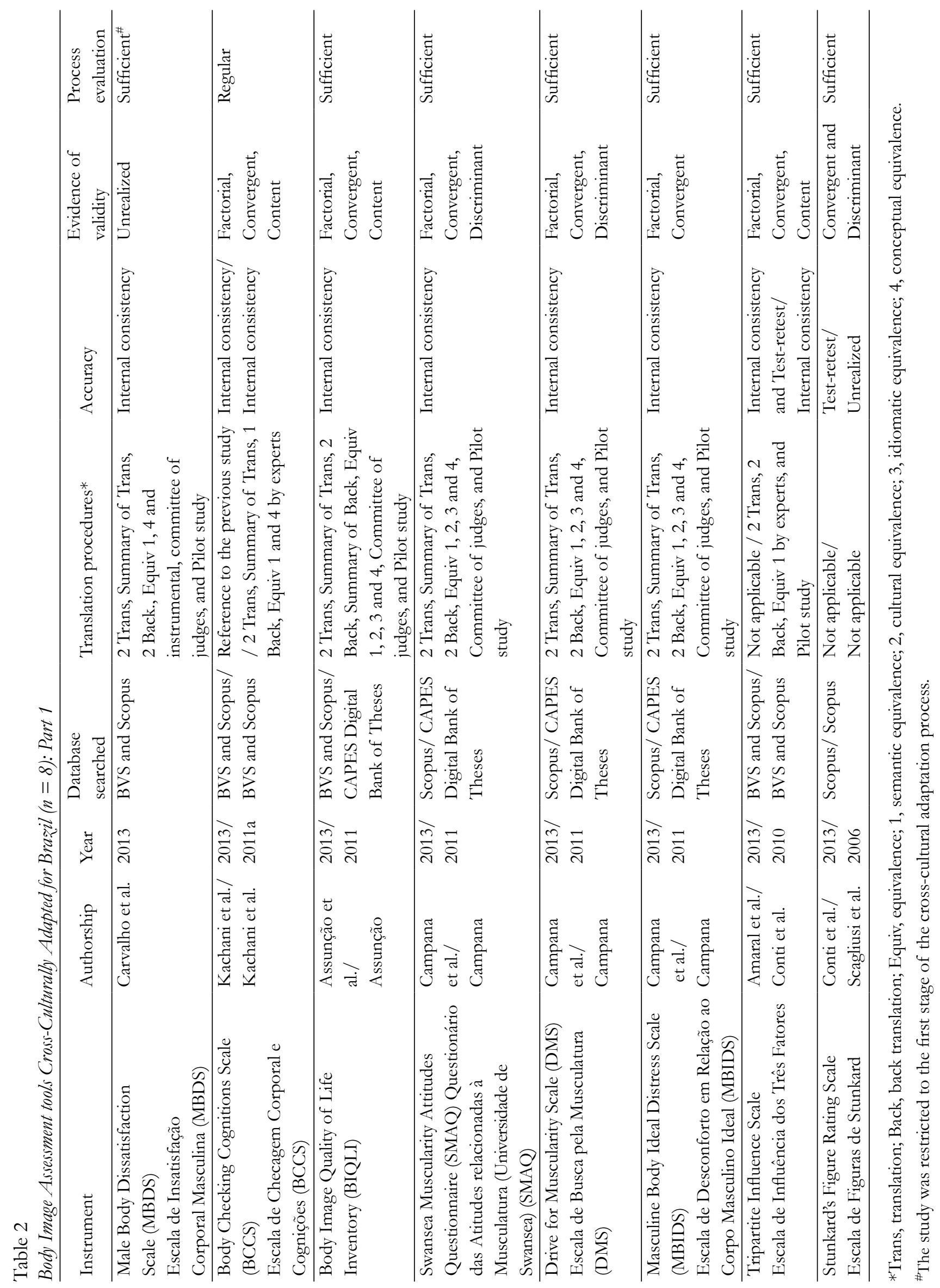


Xavier, G. S. \& cols. Assessment Instruments of Body Image

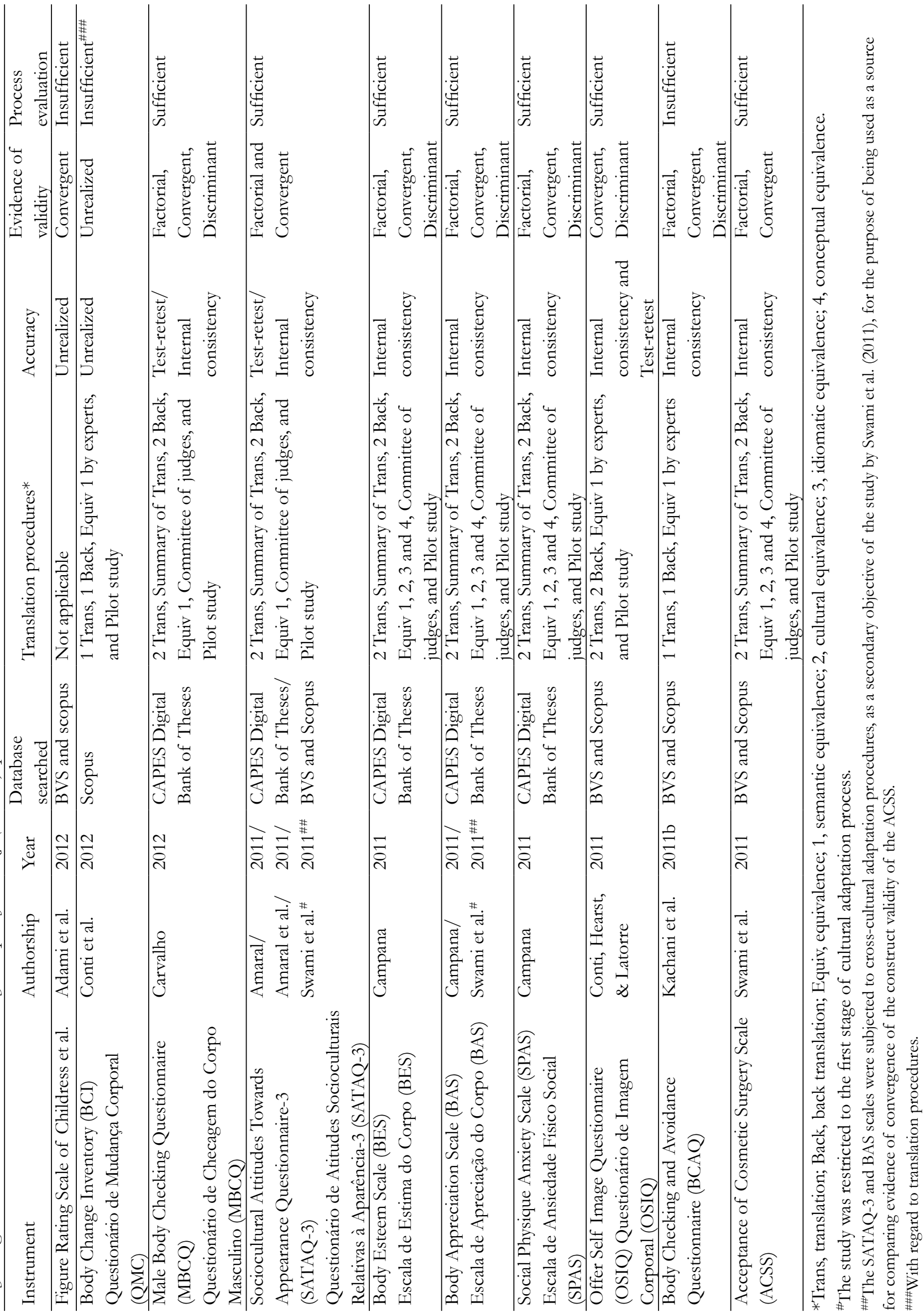




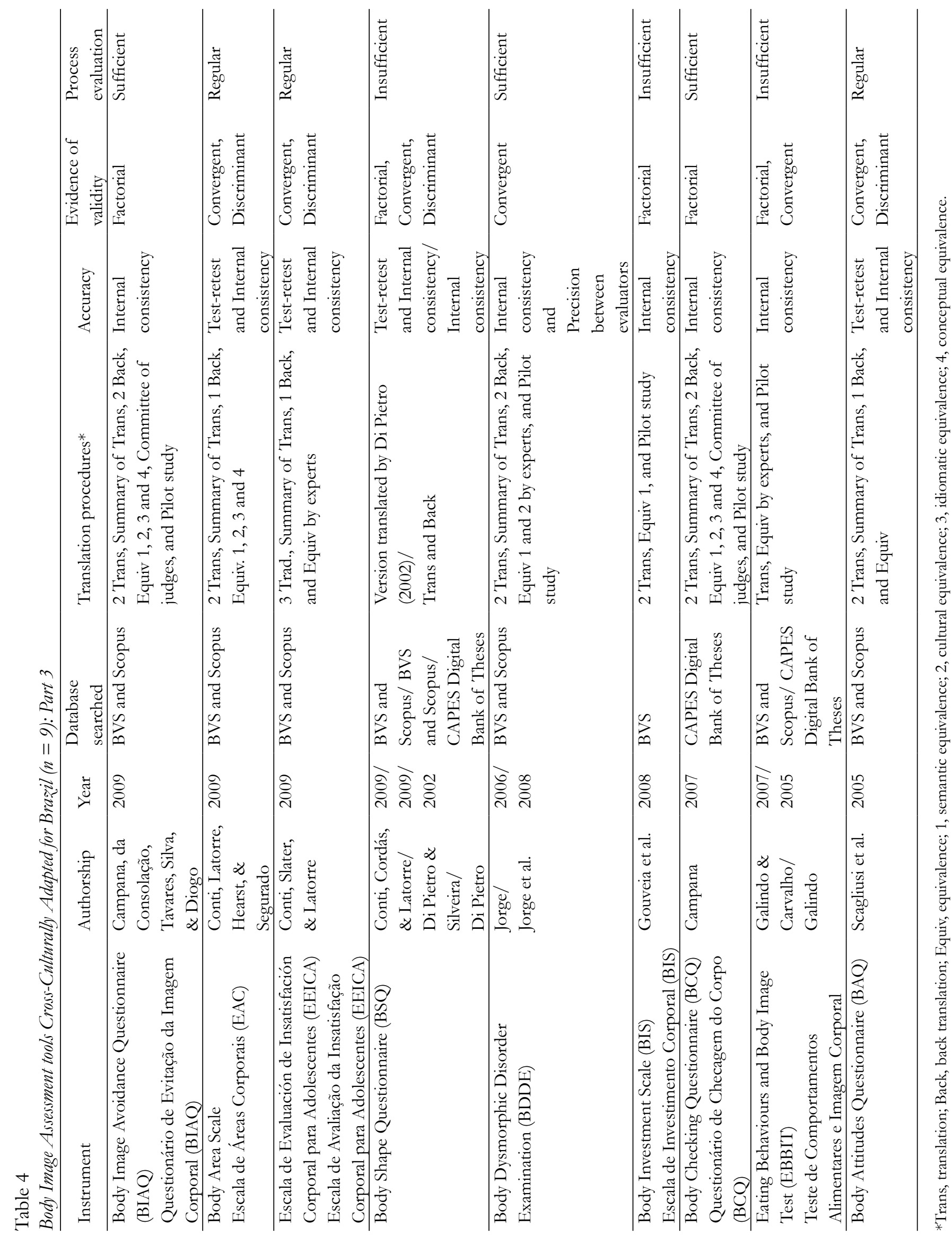




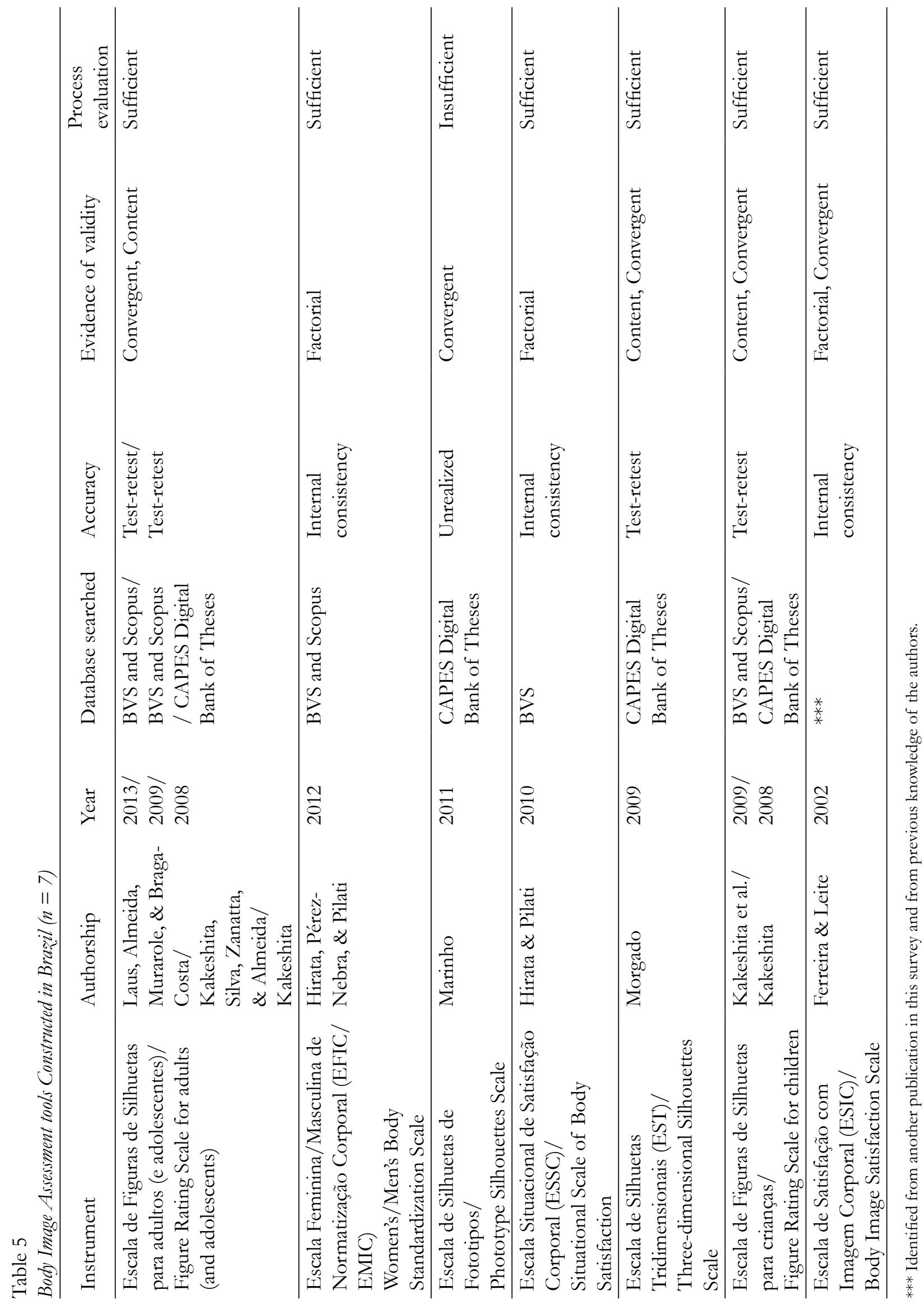


in seven of the studies (Tripartite Influence Scale, BCI, OSIQ, BCAQ, BSQ, BIS, and EBBIT), two of which $(\mathrm{BCI}$ and $\mathrm{BCAQ}$ ) performed only one translation in the first stage, so synthesis was unnecessary.

Back-translation is the third technical step, which requires that two new professionals translate the synthesized version of the translation to the original language of the instrument, also independently. Importantly, both of these professionals should have no knowledge of the original instrument or the subject that the instrument addresses (Beaton et al., 2002). This step was followed for 14 of the $25 \mathrm{BI}$ assessment tools reviewed herein (MBDS, BIQLI, SMAQ, DMS, MBIDS, MBCQ, SATAQ-3, BES, BAS, SPAS, ACSS, BIAQ, BDDE, and BCQ). Of the remaining tools, seven (BCCS, BCI, BCAQ, BAS [Body Areas Scale], EEICA, BSQ, and BAQ) performed only one back-translation. In two cases (BIS and EBBIT), no back-translation or equivalent procedure was performed. For the other two instruments, two backtranslations were performed by the same researcher (Tripartite Influence Scale and OSIQ).

The fourth technical step is the submission of all material (two translations, translations of summary, and two back-translations) to an expert committee to produce the final version of the instrument. According to Beaton et al. (2002), this committee should consist of a researcher who is experienced in methodological aspects of the instruments, a linguist, two translators, and two back-translators to judge the synthesis and a health professional who is experienced in the topic that is covered by the instrument. The decisions that are made by this committee should be followed with regard to four aspects to ensure equivalence between the original and translated versions: semantic (reciprocity of word meanings), idiomatic (maintenance of colloquialisms), cultural (consistency of situations described), and conceptual (retain the same meaning of the construct).

The presence of an expert committee with such technical characteristics occurred with the adaptation of 13 of the reviewed instruments (MBDS, BIQLI, SMAQ, DMS, MBIDS, MBCQ, SATAQ-3, BES, BAS, SPAS, ACSS, BIAQ, and BCQ). For the remaining 12, eight (BCCS, Tripartite Influence Scale, BCI, OSIQ, BCAQ, BAS [Body Areas Scale], EEICA, and BDDE) relied on the assessment of equivalence between versions (produced by translators and the original) by experts on instrument translation or the area of study of the construct. The other studies (BSQ, BIS, EBBIT, and BAQ) did not describe this step or some other procedure that could fulfill the same function. With regard to the assessment of equivalence between versions, all but one instrument (BSQ) was concerned with guaranteeing this in the adaptation.

Finally, according to Beaton et al. (2002), the fifth and final step would be to conduct a pilot study or pretest of the version of the instrument that is produced by the committee of judges to verify understanding by individuals of the target population. This step can be accomplished by applying the instrument with a sample of 30-40 individuals or having individuals who are fluent in both languages evaluate both the original and translated versions of the instrument. In both cases, the translated version may be returned to the committee of judges, if necessary, to revise the instrument or tailor specific items.

This last evaluative step was present in 19 of the adaptation procedures analyzed herein (76\% of cases). Only one of these (ACSS) opted for instrument rating by bilingual individuals. In a few studies (six instruments, $24 \%$ ), the samples were $\geq 30$ individuals (MBDS, Tripartite Influence Scale, BCI, MBCQ, SATAQ-3, and BDDE). For the other instruments (12 studies, 48\%), this pretest stage step was performed with smaller samples (BIQLI, SMAQ, DMS, MBIDS, BES, BAS, SPAS, OSIQ, BIAQ, BIS, BCQ, and EBBIT), but with justification supported by other instrument adaptation technical references, except for two cases (BIS and EBBIT). The six instruments (24\%) that did not perform this technical step (BCCS, BCAQ, BAS [Body Areas Scale], EEICA, BSQ, and BAQ) only described their application with specialists for analysis of understanding or did not mention any other equivalent procedure.

In summary, this analysis points to consensus among BI researchers of instruments with regard to the main international recommendations for the translation and cultural adaptation of assessment instruments. Although strict compliance with these guidelines was not found in all of the studies, some of the technical steps were performed in at least half of them, which reflects the technical expertise and concern of these researchers with producing adequate and valid adaptations of $\mathrm{BI}$ assessment tools from other cultures to the Brazilian context.

\section{b) Construction Procedures}

To analyze the technical procedures that are involved in the construction of psychological 
assessment tools, we followed the model proposed by Pasquali (2010), based on three poles: theoretical, empirical (experimental), and analytical (statistical). The first pole focuses on the theoretical framework that underlies the construct of interest. The second pole implements operational steps and techniques of applying the pilot version of the tool. The third pole defines statistical procedures to achieve psychometric properties. The latter refers to the same procedures that are required for cultural adaptation and is described together with them hereinafter.

Based on the first two poles (Pasquali, 2010), the researcher must first systematize all empirical evidence regarding the construct to define specific aspects on which he seeks to build the instrument. This initial step was taken in the construction of seven instruments herein (Table 5). The researcher then should know the dimensionality of the construct, allowing the precise conceptualization and its factors. Subsequently, the construct should be operationalized (i.e., construction of items that should behaviorally represent the construct; Pasquali, 2010). These procedures were taken in the construction of three verbal scales to assess BI identified in this systematic review (Women's/Men's Body Standardization Scale [EFIC/EMIC], Situational Scale of Body Satisfaction [ESSC], and Body Image Satisfaction Scale [ESIC]), in which the items were built based on existing instruments in the literature, so few alternatives were developed by the responsible researchers.

Despite the four remaining instruments match the silhouettes scales (Figure Rating Scale for adults [and adolescents], Phototype Silhouettes Scale, Threedimensional Silhouettes Scale [EST], and Figure Rating Scale for children), some analyses of the construction process of the items can be performed. The EST consists of a three-dimensional tool for the congenitally blind, the construction of which had a widely used instrument that measures the same construct in the general population. The three other scales' silhouettes were constructed based on construct characteristics (body shape) that are specific to their target population, based on prior epidemiological research. Thus, considering BI as a psychological construct that is also based on physical characteristics, we can conclude that these three studies resorted, equivalently, the source of interviews with the targeted population, as described by Pasquali (2010).

After construction, semantic and theoretical analyses of the items are necessary (i.e., evaluate their understanding and relevance to the construct; Pasquali,
2010). Among the three verbal scales, the EFIC/EMIC utilized a semantic analysis with application of the instrument in 20 individuals of the target population. The other two instruments (ESIC and ESSC) underwent evaluation by judges. With regard to the silhouette scales, most were evaluated by judges, and the threedimensional silhouette was also analyzed by the target population. Only one of them (Phototype Silhouettes Scale) did not undergo any evaluation of its items.

With regard to empirical procedures (experimental) for the construction of psychological assessment instruments, defined by Pasquali (2010), two steps are highlighted: planning instrument implementation and proper collection of empirical information. The sample should be clearly defined and specified in terms of its main features, and its size delimits in the number of factors (100 per factor) or items (5-10 individuals per item). All seven instruments that were designed to evaluate BI conformed to these guidelines.

The analysis of the instruments that were specifically constructed to evaluate BI in the Brazilian context and identified in this study indicate that experts in the field generally conducted their studies with an adequate basis in the main technical and methodological frameworks that are currently available in the scientific literature. This finding is extremely important because the construction of evaluation tools is more complex than cross-cultural adaptation, requiring greater experience and technical training of the researchers who assume this task (Pasquali, 2010).

\section{c) Psychometric Properties}

Verification of the psychometric properties of an evaluative instrument represents another important phase of the procedures associated with the cross-cultural adaptation and construction of new psychological examination techniques (Pasquali, 2010; Urbina, 2007; Borsa et al, 2012). Initial procedures (described above) do not guarantee that the translated or constructed instruments are consistent in terms of examination content or reliable. Verifying its main psychometric qualities is still necessary with regard to accuracy (or reliability), evidence of validity, and normative references (Beaton et al, 2002; Pasquali, 2010; Primi \& Nunes, 2010).

Reliability refers to the ability of an instrument to accurately assess a construct, particularly because the indices that are obtained by the evaluative technique are susceptible to environmental changes and population sample where the instrument is applied (Urbina, 2007). 
Based on the analysis of the 34 instruments in the present survey (Tables 2, 3, 4, and 5), the vast majority (30 instruments, both adaptation and construction) were subjected to procedures to assess accuracy. Only the Figure Rating Scale and Phototype Silhouettes Scale did not present data on accuracy.

Different methods can be used to evaluate reliability, namely internal consistency, test-retest reliability, parallel forms, and precision among raters (Pasquali, 2010). Among the instruments that have been evaluated for accuracy, 22 employed one method, and nine used two methods.

Internal consistency and test-retest reliability were the most often employed. The former was used in 27 of the instruments, and the latter was used in 12 of the instruments, alone or combined with other procedures. According to Urbina (2007), indices of internal consistency seek to require consistency between the items of an instrument. This method is one of the most known and applied for examination precision, which may explain its wide use among the instruments analyzed in the present study. Only one study (BDDE) utilized examination between evaluators as an accuracy strategy, which was performed by comparing the evaluation of the same instrument by two independent professionals (Anastasi \& Urbina, 2000).

The equity method of parallel forms was not used, likely because of technical difficulties that are inherent to the development of appropriate instruments to examine BI. Although used in 12 cases, test-retest reliability was seldom used, which is concerning given the importance of this method for verifying the temporal stability of the measure. In summary, the findings concerning accuracy of the instruments that were identified in this survey are positive indicators of the reliability of Brazilian instruments that are used to assess BI.

With regard to psychometric properties, evaluating evidence of validity of the instruments is necessary, which has historically been defined as the instrument's ability to adequately measure the construct that it seeks to examine (Anastasi \& Urbina, 2000). According to Primi, Muniz, and Nunes (2009) and Primi and Nunes (2010), the didactic systematization of information concerning the validity of a psychological assessment tool should revolve around five main areas: (1) evidence based on content (representativeness of the test items to cover the area in question), (2) evidence based on the response process (mental processes involved in the proposed tasks and their relationship to the construct in question), (3) evidence based on internal structure (structure of correlations between items and between subtests that assess similar constructs), (4) evidence based on relationships with external variables (convergent validity, discriminant validity, and test predictive capacity through external criteria), and (5) evidence based on the testing consequences (social consequences).

All of the BI assessment instruments covered herein, either adapted or constructed, underwent a procedure to assess evidence of validity. The only two studies that did not examine the validity of the instruments consisted of work that described translation and semantic equivalence, indicating that they were restricted only to the first stage of cultural adaptation (MBDS and BCI).

Among the 32 instruments that performed a procedure to assess validity, the majority (19 instruments, $59.3 \%$ ) involved at least two types of evidence, most often internal structure analysis and relationships with external variables. Predominate in these studies were factor analysis of the results and analysis of convergence/divergence between results of the BI evaluation tools. Another 13 studies that had indicators of validity utilized only one source of evidence, again prioritizing analyses of internal structure and relationships with external variables (convergence/divergence between instruments or external criteria). In neither case was the exclusive use of content analyses of the instruments by judges utilized as a source of validity, which qualifies the evidence identified as good flags about the BI, as theoretically desired. Based on this analysis, we can conclude that the BI assessment tools that were identified in this literature review were positive indicators, arising from one or two sources of evidence of validity, that effectively examine the theoretical trait that the instrument purports to measure (Urbina, 2007; Primi et al., 2009).

Analyses of convergence of the results of BI assessment tools were the most frequently used to obtain evidence of validity (26 studies). This type of analysis focuses on comparing the results with other instrument measures (i.e., previously validated instruments) that examine the same construct. High concordance between the two is considered evidence of convergent validity (Primi \& Nunes, 2010). The frequent application of this method for almost all of the studies reviewed herein corroborates the frequency of their use in the literature, which is justified by the ease of this process (Urbina, 2007). The same could be said with the use of discriminant analysis (identified in $14 \mathrm{BI}$ 
assessment tools), the purpose of which is to verify that the assessed construct is not correlated with variables from which it should theoretically differ. Both sources of evidence of validity are governed by the same process of data collection (i.e., application of other instruments for comparison), setting up an instrument of relations with external variables.

Also within this group of validity of evidence (i.e., relationships with external variables) are procedures that verify the prediction that the instrument does relative to another variable, with criteria that make distinctions between groups with different characteristics (Primi \& Nunes, 2010). This validation method is applicable for diagnostic assessment, especially in clinical populations. None of the studies identified herein used this alternative technique, possibly because of the time that is required between the instrument's application and predictive criteria that may make this an impractical method (Urbina, 2007; Primi et al., 2009).

Factor analysis procedures were also quite frequently identified in the studies described herein, which occurred in 21 articles that examined the internal structure of the instruments. This finding is a positive indicator of validity, indicating that the researchers in the area of BI are concerned with producing appropriate tools for use in Brazil and possess the proper technical expertise.

Finally, the content-related validity results were based on judges or specialists who analyzed the representativeness, clarity, and relevance of the items that comprise the instruments with regard to the examined construct (Cassep-Borges, Balbinotti, \& Teodoro, 2010). Among the six instruments that examined this (BCCS, BIQLI, Tripartite Influence Scale, Figure Rating Scale for adults [and adolescents], EST, and Figure Rating Scale for children), all of them underwent another scan strategy to provide evidence of validity, at least in one of the publications about the same instrument. Anastasi and Urbina (2000) stated that validity related to content should not replace other methods but rather be added to them when analyzing the quality of the instrument.

In summary, the analysis of validation procedures that were employed in BI assessment tools in the present survey indicates a consensus among researchers in the BI field that the primary national and international technical recommendations should be followed. Among the 27 adapted instruments that were analyzed, the majority (17 instruments) underwent a set of procedures that were considered sufficient for cross-cultural adaptation. Additionally, four instruments were considered "regular" with regard to methodological care (BCCS, BAS [Body Areas Scale], EEICA, and BAQ). The other six instruments were deemed to employ "insufficient" technical strategies (Figure Rating Scale, BCI, BCAQ, BSQ, BIS, and EBBIT).

With regard to psychometric properties, checking indicators of validity is fundamentally important for adapting and developing assessment tools, in addition to the authors who lead these processes, providing a theoretical basis for use by allowing interpretations and plausible inferences based on empirical data (Pasquali, 2010; Primi \& Nunes, 2010; Urbina, 2007). Among the instruments evaluated herein, all of them underwent a procedure to check evidence of validity. Only two instruments (Figure Rating Scale and Phototype Silhouettes Scale) did not evaluate accuracy in their processes of adaptation or construction, so they were considered insufficient. In two other cases (MBDS and $\mathrm{BCI}$ ), procedures were not conducted to verify evidence of validity of the instruments. These studies were restricted to the first stage of the cross-cultural adaptation process, and the authors alerted readers to the need for subsequent validation studies before using the instruments.

\section{Final Considerations}

The mapping of BI assessment tools confirms a sharp increase in such studies in Brazil (Tavares et al., 2010). A large proportion of the studies that adapted and constructed $\mathrm{BI}$ instruments were published in the past two decades, indicating that it is a recent theme in the national scientific literature.

The vast majority of the analyzed instruments followed national and international recommendations regarding the adaptation and construction of evaluative techniques, ensuring adequate technical quality of their end products. Despite these findings, however, some of the studies identified herein lacked the inclusion of certain stages of cultural adaptation and methodological rigor, especially with regard to the choice of qualified judges and experts who participated in the cultural adaptation process. A notable tendency to use university samples to adapt instruments was found, which is justified by easy access, but such samples limit the generalizability of application to other individuals in the population.

Considering the ethical aspects of the crosscultural adaptation of psychological assessment instruments, Cassep-Borges et al. (2010) indicated that 
formal authorization must be secured from the author of the original instrument. Although most studies stated that they obtained such permission, seven instruments (Tripartite Influence Scale, Figure Rating Scale, BCI, OSIQ, BAS [Body Areas Scale], BDDE, and BIS) did not mention obtaining permission from the original authors. Two other cases (BCCS and BCAQ) made no mention of contact with the original authors of the respective scales or authorization for such use. In one case (BSQ), the researchers reported that they were unable to contact the original authors of the instrument. This contact between professionals goes beyond ethical care and enables the instrument's original author to contribute to the adaptation process.

This review of the scientific literature on BI assessment tools was conducted to systematize the current state of instruments that are available for use in the Brazilian context and the methodological procedures that support their adaptation and construction. The present study may stimulate future research that adapts or constructs new instruments of BI assessment in Brazil. Our central objective was to synthesize the efforts of Brazilian researchers and highlight methodological guidelines that support adaptation and construction processes.

\section{References}

Adami, F., Schlickmann Frainer, D. E., de Souza Almeida, F., de Abreu, L. C., Valenti, V. E., \& PIca Demarzo, M. M. (2012). Construct validity of a figure rating scale for Brazilian adolescents. Nutrition Journal, 11, 24. doi:10.1186/1475-2891-11-24

Amaral, A. C. S. (2011). Adaptação transcultural do sociocultural Attitudes Towards Appearance Questionnaire - 3 (SATAQ - 3) para a população brasileira (Dissertação de mestrado). Universidade Federal de Juiz de Fora, Juiz de Fora.

Amaral, A. C. S., Cordás, T. A., Conti, M. A., \& Ferreira, M. E. C. (2011). Semantic equivalence and internal consistency of the Brazilian Portuguese version of the Sociocultural Attitudes Towards Appearance Questionnaire-3 (SATAQ-3). Reports in Public Health, 27(8), 1487-1497. doi:10.1590/ S0102-311X2011000800004

Amaral, A. C. S., Ferreira, M. E. C., Scagliusi, F. B., Costa, L. S., Cordás, T. A., \& Conti, M. A. (2013). Avaliação psicométrica da escala de influência dos três fatores (EITF). Psicologia: Reflexão e Crítica, 26(2), 213-221. doi: 10.1590/S0102-79722013000200001

Anastasi, A., \& Urbina, S. (2000). Testagem psicológica (M. A. V. Veronese, translator). Porto Alegre: Artes Médicas.

Assunção, F. F. O. (2011). Body image quality of life inventory - BIQLI: Adaptação para o português e validação para pacientes brasileiros, vitimas de queimaduras (Dissertação de mestrado). Escola de Enfermagem de Ribeirão Preto, Universidade de São Paulo, Ribeirão Preto.

Assunção, F. F. O., Dantas, R. A. S., Ciol, M. A., Gonçalves, N., Farina Junior, J. A., \& Rossi, L. A. (2013). Reliability and validity of the body image quality of life inventory: Version for Brazilian burn victims. Research in Nursing and Health, 36, 299-310. doi: 10.1002/nur.21538

Banfield, S., \& McCabe, M. (2002). An evaluation of the construct of body image. Adolescence, 37(146), 373-393. Retrieved from http://www.ncbi.nlm. nih.gov/pubmed/12144166

Beaton, D., Bombardier, C., Guillemin, F., \& Ferraz, B. M. (2002). Recommendations for the cross-cultural adaptation of health status measures. American Academy of Orthopaedic Surgeons. Institute for Work \& Health.

Borsa, J. C., Damásio, B. F., \& Bandeira, D. R. (2012). Adaptação e validação de instrumentos psicológicos entre culturas: Algumas considerações. Paidéia, 22(53), 423-432. doi: 10.1590/S0103-863X2012000300014

Campana, A. N. N. B. (2007). Translation, transcultural adaptation and validation of "Body Image Avoidance Questionnaire (BIAQ)" and of "Body Checking Questionnaire (BCQ)" for Portuguese language of Brazil (Dissertação de mestrado). Faculdade de Educação Física. Universidade Estadual de Campinas, Campinas, 2007.

Campana, A. N. N. B. (2011). Relationships among body image dimensions: $A$ study in Brazilian males ( $\mathrm{PhD}$ thesis). Department of Physical Education, University of Campinas, Campinas.

Campana, A. N. N. B., \& Tavares, M. C. G. C. F. (2009). Avaliação da imagem corporal: Instrumentos e diretrizes para pesquisa. São Paulo: Phorte. 
Campana, A. N. N. B., Campana, M. B., \& Tavares, M. C. G. C. F. (2009). Scales for body image evaluation in eating disorders in Brazil. Avaliação Psicológica, 8(3), 437-446. Retrieved from http://pepsic.bvsalud.org/pdf/avp/v8n3/v8n3a15.pdf

Campana, A. N. N. B., da Consolação, M., Tavares, M. C. G. C. F., da Silva, D., \& Diogo, M. J. (2009). Translation and validation of the body image avoidance questionnaire (BIAQ) for the Portuguese language in Brazil. Behavior Research Methods, 41(1), 236-243. doi: 10.3758/BRM.41.1.236.

Campana, A. N. N. B., Tavares, M. C. G. C. F., Swami, V., \& Silva, D. (2013). An examination of the psychometric properties of Brazilian Portuguese translations of the drive for muscularity scale, the swansea muscularity attitudes questionnaire, and the masculine body ideal distress scale. Psychology of Men and Masculinity, 14(4), 376-388. doi: 10.1037/ a0030087

Carvalho, P. H. B. (2012). Adaptação transcultural do Male Body Checking Questionnaire (MBCQ) para a lingua portuguesa do Brasil (Dissertação de mestrado). Universidade Federal de Juiz de Fora, Juiz de Fora.

Carvalho, P. H. B., Ferreira, M. E. C., Kotait, M., Teixeira, P. C., Hearst, N., Cordás, T. A. (2013). Conceptual, semantic, and instrumental equivalences: Preliminary analysis of the Brazilian Portuguese version of the Male Body Dissatisfaction Scale (MBDS). Reports in Public Health, Rio de Janeiro, 29(2), 403-409. doi: 10.1590/S0102-311X2013000600027

Cash, T. F. (2011).Cognitive-behavioral perspectives on body image. In: T. F. Cash, \& L. Smolak (Eds.). Body image: a handbook of science, practice, and prevention (pp. 39-47). New York: The Guilford.

Cassep-Borges, V., Balbinotti, M. A. A., \& Teodoro, M. L. M. (2010). Tradução e validação de conteúdo: Uma proposta para a adaptação de instrumentos. In L. Pasquali (Ed.), Instrumentação psicológica: Fundamentos e práticas (pp. 506-520). Porto Alegre: Artmed.

Conti, M. A., Cordás, T. A., \& Latorre, M. R. D. O. (2009). A study of the validity and reliability of the Brazilian version of the Body Shape Questionnaire (BSQ) among adolescents. Revista Brasileira de Saúde Materno Infantil, 9(3), 331-338. doi:10.1590/ S1519-38292009000300012
Conti, M. A., Ferreira, M. E. C., Amaral, A. C. S., Hearst, N., Cordás, T. A., \& Scagliusi, F. B. (2012). Semantic equivalence of the Brazilian Portuguese version of the "Body Change Inventory." Ciencia \& Saúde Coletiva, 17(9), 2457-2469. doi: 10.1590/ S1413-81232012000900026

Conti, M. A., Ferreira, M. E. C., de Carvalho, P. H. B., Kotait, M. S., Paulino, E., Costa, L. S. (2013). Stunkard figure rating scale for brazilian men. Eating and Weight Disorders, 18, 317-322. doi: 10.1007/ s40519-013-0037-8.

Conti, M. A., Hearst, N., \& Latorre, M. R. D. O. (2011). Translation and validation for Brazil of the body image scale for adolescents: Offer self-image auestionnaire (OSIQ). Brazilian Journal of Epidemiology, 14(3), 508-521. doi: 10.1590/ S1415-790X2011000300015.

Conti, M. A., Latorre, M. R. D. O., Hearst, N., \& Segurado, A. (2009). Cross-cultural adaptation, validation and reliability of the body area scale for Brazilian adolescents. Reports in Public Health, 25(10), 2179-2186. doi: 10.1590/ S0102-311X2009001000009

Conti, M. A., Scagliusi, F., Queiroz, G. K. O., Hearst, N., \& Cordás, T. A. (2010). Cross-cultural adaptation: Translation and Portuguese language content validation of the Tripartite Influence Scale for body dissatisfaction. Reports in Public Health, 26(3), 503-513. Retrieved from http://www.ncbi.nlm. nih.gov/pubmed/20464069

Conti, M. A., Slater, B., \& Latorre, M. R. D. O. (2009). Validity and reproducibility of Escala de Evaluación da Insatisfación Corporal para Adolescentes. Revista Saúde Pública, 43(3), 515-524. doi: 10.1590/ S0034-89102009000300016

Di Pietro, M. C. (2002). Validade interna, dimensionalidade e desempenho da escala BSQ-"Body Shape Questionnaire" em uma população de estudantes universitários (Dissertação de mestrado). Escola Paulista de Medicina da Universidade Federal de São Paulo.

Di Pietro, M., \& Silveira, D. X. (2009). Internal validity, dimensionality and performance of the Body Shape Questionnaire in a group of Brazilian college students. Revista Brasileira de Psiquiatria, 31(1), 21-24. Retrieved from http://www.scielo.br/pdf/ rbp/v31n1/253.pdf 
Federal Council of Psychology. (2003). Resolution 002/2003. Brasília, DF: CFP. Available in http:// www.pol.org.br.

Ferreira, M. C., \& Leite, N. G. M. (2002). Adaptation and validation of an instrument for evaluation of body image satisfaction. Avaliação Psicológica, 2, 141-149. Retrieved from http://pepsic.bvsalud. org/pdf/avp/v1n2/v1n2a07.pdf

Galindo, E. M. C. (2005). Translation, adaptation and validation of Eating Behaviours and Body Image Test for use with female children of Ribeirão Preto (Master dissertation). Escola de Enfermagem de Ribeirão Preto, Universidade de São Paulo, Ribeirão Preto.

Galindo, E. M. C., \& Carvalho, A. M. P. (2007). Translation, adaptation and internal consistency evaluation of the Eating Behaviours and Body Image Test for female children. Brazilian Journal of Nutrition, 20(1), 47-54. doi: 10.1590/ S1415-52732007000100005

Gardner, R. M., \& Brown, D. L. (2010). Body image assessment: a review of figural drawing scales. Personality and Individual Differences, 48(2), 107-111. Retrieved from http://www.sciencedirect.com/ science/article/pii/S019188690900364X

Gonçalves, C. O., Tavares, M. C. G. C. F., Campana, A. N. N. B., Cabello, C., \& Shimo, A. K. K. (2012). Instruments to evaluate body image in women with breast cancer. Psicologia: Teoria e Pratica, 14(2), 43-55. Retrieved from http://pepsic. bvsalud.org/scielo.php? script=sci_arttext\&pid $=$ S1516-36872012000200004

Gouveia, V. V., Santos, C. A., Gouveia, R. S. V., Santos, W. S., \& Pronk, S. L. (2008). Body investment scale (BIS): evidences of its factor validity and reliability. Avaliação Psicológica, 7(1), 57-66. Retrieved from http://pepsic.bvsalud.org/scielo.php?pid=S167704712008000100008\&script=sci_arttext

Hirata, E., \& Pilati, R. (2010). Development and preliminary validation of the Body Satisfaction Situational Scale-ESSC. Psico-USF, 15(1), 1-11. doi: 10.1590/ S1413-82712010000100002

Hirata, E., Perez-Nebra, A. R., \& Pilati, R. (2012). Development and validation of Brazilian scales for measuring perception and internalization of body norms. Psicologia: Reflexão e Crítica, 25(1), 48-59. doi: 10.1590/S0102-79722012000100007
Jorge, R. T. B. (2006). Brazilian version of body dysmorphic disorder examination (Master dissertation). Universidade Federal de São Paulo, São Paulo.

Jorge, R. T. B., Sabino Neto, M., Natour, J., Veiga, D. F., Jones, A., \& Ferreira, L. M. (2008). Brazilian version of the body dysmorphic disorder examination. São Paulo Medical Journal, 126, 87-95. doi:10.1590/ S1516-31802008000200005

Kachani, A. T., Barbosa, A. L. R., Brasiliano, S., Cordás, T. A., Hochgraf, P. B., \& Conti, M. A. (2011a). Portuguese (Brazil) translation, cross-cultural adaptation and content validity of Body Checking Cognitions Scale - BCCS. Archives of Clinical Psychiatry (São Paulo), 38(1), 13-18. doi:10.1590/ S0101-60832011000100004

Kachani, A. T., Barroso, L. P., Brasiliano, S., Hochgraf, P. B., Cordás, T. A., \& Conti, M. A. (2013). Psychometric evaluation of the Body Checking Cognitions Scale (BCCS) Portuguese version. Perceptual \& Motor Skills, 116(1), 175-186. Retrieved from http:// www.ncbi.nlm.nih.gov/pubmed/23829144

Kachani, A. T., Hochgraf, P. B., Brasiliano, S., Barbosa, A. L. R., Cordás, T. A., \& Conti, M.A. (2011b). Psychometric evaluation of the "Body Checking and Avoidance Questionnaire - BCAQ" adapted to Brazilian Portuguese. Eating and Weight Disorders, 16, e293-e299. Retrieved from http://www.ncbi. nlm.nih.gov/pubmed/22526137

Kakeshita, I. S. (2008). Adaptation and validation of a Figure Rating Scales for Brazilian children and adults (Doctoral thesis). Faculdade de Filosofia, Ciências e Letras de Ribeirão Preto, Universidade de São Paulo, Ribeirão Preto.

Kakeshita, I. S., Silva, A. I. P., Zanatta, D. P., \& Almeida, S.S. (2009). Construção e fidedignidade teste-reteste de escalas de silhuetas Brasileiras para adultos e crianças. Psicologia: Teoria e Pesquisa, 25(2), 263-270. doi: 10.1590/S0102-37722009000200015

Laus, M. F., Almeida, S. S., Murarole, M. B., \& Braga-Costa, T. M. (2013). Estudo de validação e fidedignidade de escalas de silhuetas brasileiras em adolescentes. Psicologia: Teoria e Pesquisa, 29(4), 403409. doi: 10.1590/S0102-37722013000400006

Laus, M. F., Kakeshita, I. S., Braga-Costa, T. M., Ferreira, M. E. C., Fortes, L. S., \& Almeida, S. S. (2014). Body image in Brazil: Recent advances in the state of knowledge and methodological 
issues. Revista de Saúde Pública, 48(2), 331-346. doi: 10.1590/S0034-8910.2014048004950

Marinho, S. M. S. A. (2011). Construção e validação de escalas de silhueta de fototipos para avaliação nutricional de mulheres adultas (Dissertação de mestrado). Faculdade de Medicina, Universidade Federal Fluminense, Niterói.

Morgado, F. F. R. (2009). Validação e confiabilidade de uma escala de silhuetas tridimensionais para o cego congênito (Dissertação de mestrado). Universidade Federal de Juiz de Fora.

Pasquali, L. (2010). Instrumentação Psicológica: Fundamentos e Práticas. Porto Alegre: Artmed.

Primi, R., \& Nunes, C. H. S. S. (2010). O SATEPSI: desafios e propostas de aprimoramento. In: Avaliação psicológica: Diretrizes na regulamentação da profissão (pp. 129-148). Brasília (DF): Conselho Federal de Psicologia.

Primi, R., Muniz, M., \& Nunes, C. H. S. S. (2009). Definições contemporâneas de validade de testes psicológicos. In C. S. Hutz (Ed.), Avanços e polêmicas em avaliação psicológica (pp. 243-263). São Paulo: Casa do Psicólogo.

Scagliusi, F. B., Alvarenga, M., Polacow, V. O., Cordás, T. A., de Oliveira Queiroz, G. K., Coelho, D. (2006). Concurrent and discriminant validity of the Stunkard's Figure Rating Scale adapted into
Portuguese. Appetite, 47(1), 77-82. Retrieved from http://www.ncbi.nlm.nih.gov/pubmed/16750589

Scagliusi, F. B., Polacow, V. O., Cordas, T. A., Coelho, D., Alvarenga, M., Philippi, S. T. (2005). Psychometric testing and applications of the Body Attitudes Questionnaire translated into Portuguese. Perceptual and Motor Skills, 101(1), 25-41. Retrieved from http://www.ncbi.nlm.nih.gov/pubmed/16350606

Swami, V., Campana, A. N. N. B., Ferreira, L., Barretta, S., Harrisa, A. S., \& Tavares, M. C. G. C. F. (2011). The Acceptance of cosmetic surgery scale: Initial examination of its factor structure and correlates among Brazilian adults. Body Image, 8(2), 179-185. doi: $10.1016 /$ j.bodyim.2011.01.001

Tavares, M. C. G. C. F., Campana, A. N. N. B., Tavares Filho, R. F., \& Campana, M. B. (2010). Avaliação perceptiva da imagem corporal: História, reconceituação e perspectivas para o Brasil. Psicologia em Estudo, Maringá, 15(3), 509-518. Retrieved from http://www.scielo.br/pdf/pe/v15n3/ v15n3a08.pdf

Urbina, S. (2007). Fundamentos de testagem psicológica (C. Dornelles, translator). Porto Alegre: Artmed.

Recebido: 07/08/2014

Primeira reformulação: 16/01/2015

Segunda reformulação: 24/03/2015

Aprovado: 29/06/2015 
Sobre os autores:

Gabriela Salim Xavier é psicóloga (FFCLRP-USP), mestre em Psicologia pela Faculdade de Filosofia, Ciências e Letras de Ribeirão Preto-USP, pesquisadora do Laboratório de Nutrição e Comportamento e realiza estudos sobre imagem corporal.

E-mail: gabrielasalimxavier@gmail.com

Sonia Regina Pasian é psicóloga (FFCLRP-USP), professora associada do Departamento de Psicologia da Faculdade de Filosofia, Ciências e Letras de Ribeirão Preto-USP, coordenadora do Centro de Pesquisas em Psicodiagnóstico - FFCLRP-USP, membro do Conselho Consultivo da Associação Brasileira de Rorschach e Métodos Projetivos (ASBRo) e editora associada da revista Avaliação Psicológica (IBAP).

E-mail:srpasian@ffclrp.usp.br

Sebastião Sousa Almeida é psicólogo (FFCLRP-USP), professor titular da Faculdade de Filosofia, Ciências e Letras de Ribeirão Preto-USP, membro do corpo editorial das revistas Nutritional Neuroscience (USA), Psychology \& Neuroscience (Brasil) e Estudos de Psicologia (Natal), líder do Grupo de Pesquisa Nutrição e Comportamento, do Conselho Nacional de Desenvolvimento Científico e Tecnológico (CNPq) e, atualmente, é coordenador do Comitê de Assessoramento da área de Psicologia e Serviço Social do CNPq.

E-mail: sebasalm@usp.br

Contato com os autores:

Departamento de Psicologia - FFCLRP - USP

Sebastião Sousa Almeida

E-mail: sebasalm@usp.br

Av. Bandeirantes, 3900 - Monte Alegre

Ribeirão Preto/SP

CEP: $14040-901$ 
